\title{
Revealing the Manifestations of Neoliberalism in Academia: Academic Collective Action in Turkey
}

\author{
Canan Coşkan ${ }^{1}$, Yasemin Gülsüm Acar², Aydın Bayad ${ }^{3}$
}

[1] Independent researcher with scientific affiliation to Institute for Interdisciplinary Research on Conflict and Violence, Bielefeld University, Bielefeld, Germany. [2] Department of Psychology, School of Social Sciences, University of Dundee, Dundee, Scotland, United Kingdom. [3] Institute for Interdisciplinary Research on Conflict and Violence, Bielefeld University, Bielefeld, Germany.

Journal of Social and Political Psychology, 2021, Vol. 9(2), 401-418, https://doi.org/10.5964/jspp.7077

Received: 2019-11-12 • Accepted: 2021-06-18 • Published (VoR): 2021-09-07

Handling Editor: Johanna Vollhardt, Clark University, Worcester, MA, USA

Corresponding Author: Canan Coşkan, Independent researcher, İstanbul, Turkey. E-mail: canancoskan@gmail.com

Supplementary Materials: Materials [see Index of Supplementary Materials]

\begin{abstract}
Academic Collective Action (ACA) stands as a small-scale collective action for social change toward liberation, independence and equity in academia. Academic collectives in Turkey, as an example of ACA, prefigure building academia outside the university by emphasizing the extent to which neoliberal academia has already prepared the groundwork for more recent waves of oppression. In this research, we aim to reveal the manifestations of neoliberalism in ACA as captured with prominent social/political psychological concepts of collective action. We conducted semi-structured interviews with 21 dismissed academics to understand the social and political psychological processes in academic collectives. The narrations of ACA were accompanied by manifestations of neoliberalism as experienced by dismissed academics. We found that, as follows from the existing conceptual tools of collective action, neoliberalism serves as an embedded contextual factor in the process of ACA. This becomes mostly visible for grievances but also for collective identifications, politicization, motivations, finding/allocating resources and sustaining academic collectives. We provide a preliminary basis to understand the role of neoliberalism in organization, mobilization and empowerment dynamics of collective action.
\end{abstract}

\section{Keywords}

academia, neoliberalism, oppression, collective action, academic mobilization, Turkey

\section{Özet}

Akademik Kolektif Eylem (AKE), akademide özgürleşmeye, bağımsızlığa ve hakkaniyete doğru sosyal değişime yönelik dar çaplı kolektif eylem olarak kendini ortaya koyuyor. Bir AKE örneği olarak Türkiye'deki akademik kolektifler, neoliberal akademinin devamında gelen baskılar için hazırlamış olduğu zeminin boyutunu vurgulayarak üniversite dışında geleceğin muhtemel ve başka bir akademi biçimini kurmayı günümüzde betimliyor. Bu araştırmada, AKE'de neoliberalizmin tezahürlerini kolektif eyleme değin öne çıkan sosyal/politik psikoloji kavramlarıyla ortaya koymayı amaçlıyoruz. Bu kapsamda, akademik kolektiflerdeki sosyal ve politik psikolojik süreçleri anlamak amacıyla çalışma hakları ellerinden alınmış 21 akademisyen ile yarı yapılandırılmış görüşmeler yürüttük. Akademisyenlerin deneyimledikleri haliyle neoliberalizm tezahürleri AKE anlatılarına eşlik etti. Kolektif eyleme yönelik mevcut kavramsal araçlardan takip edebildiğimiz haliyle neoliberalizmin AKE sürecinde gömülü bir bağlamsal etken rolü olduğunu ortaya çıkardık. Neoliberal tezahürler, en fazla toplu mağduriyet kaynaklı kızgınlıklarda ortaya çıktı fakat kolektif aidiyetliklerde, politikleşmede, motivasyonlarda ve kaynak bulma/ayırma ile akademik kolektifleri devam ettirme konularına da eşlik ettiğini gözlemledik. Böylelikle, bu çalışmayla kolektif eylemin örgütlenme, hareketlenme ve güçlenme dinamiklerinde neoliberalizmin rolünü anlamaya yönelik bir ilk zemin sunuyoruz. 


\section{Anahtar kelimeler}

akademi, neoliberalizm, baskı, kolektif eylem, akademik hareketlenme, Türkiye

\section{Non-Technical Summary}

\section{Background}

As universities become more and more dictated by neoliberal economy politics that aim to sustain existing inequalities and to attack academic freedom and independence, academics have sought to build other ways to do science and produce scientific knowledge for/with the people at the borders of the existing system, though Academic Collective Action (ACA). However, we still lack sufficient knowledge to make sense of this collective action in the context of the neoliberal system in which we all live. The recent mobilization of academics to build academic collectives outside of the university system in Turkey provided us a crucial opportunity to get a preliminary understanding of such a context in terms of collective action.

\section{Why Was This Study Done?}

The existing understanding of neoliberalism's role in social and political psychological processes such as in collective action is based on its ideological roots. We do not exactly know how it shapes the environment we live in, exits and resists beyond being an ideological concept or tool. For example, in the case of universities, how do neoliberal politics manifest themselves and thus affect academics? Or how can economic sustainment of Academic Collective Action (ACA) be met without relying on such manifestations? To gain a first insight into such questions, we aimed to understand the degree to which neoliberalism is reflected in one specific example of ACA in Turkey, where academics organized to build academic collectives outside of universities after being attacked by the government. Beyond understanding it as an ideology, we considered neoliberalism as a structural and contextual factor constantly interacting with our lives.

\section{What Did the Researchers Do and Find?}

Twenty-one academics who were organized or interested in academic collectives in Turkey told us their stories of academic life in the university, their engagements with and their thoughts about academic collectives. Following the social and political psychological lenses of collective action, we analyzed their responses in terms of the ways in which neoliberalism manifests itself. We found that participants narrated neoliberalism-related issues such as an unfair academic competition, work overload, precarity, debt to state, privatized knowledge production and surveilled and censored academic freedom mostly in explaining their grievances about the existing economic-political system in the universities, but also to some degree in expressing how they identify, politicize and become motivated with their group, and describing how they find resources and sustain academic collectives.

\section{What Do These Findings Mean?}

Engaging in and sustaining collective action can sometimes be difficult under the neoliberal system; however, the contentions against this system can be also a source of motivation to mobilize. This study shows us that neoliberalism, as manifested in economic and social policies in universities and in the academia in general, can be a source of grievance-but also an obstacle to preparing and using material and psychological resources, a motive for dissident identification, and a barrier against being empowered to differing degrees before and during ACA.

As researchers living in a neoliberal system and working in a neoliberalized academic context, it follows that our survival and resistance practices can also bear the marks of neoliberalism (Biner, 2019). One way to uncover these marks is to focus on how (much) they are reflected in our repertoires of resistance in the process of collective action (e.g., Erdem \& Akın, 2019). In Turkey, where political oppression is increasing and the costs of social protest are perceptibly tremendous (e.g., imprisonment, travel ban, denial of civil rights), we previously considered dismissed academics engaged or interested in academic collectives as subjects voicing social problems and ingroup-oriented resistance as collective action targeted at changing these problems (Acar \& Coşkan, 2020). Currently, we further argue that their 
repertoire of resistance against neoliberalism can be a crucial indicator of the dominant socio-political and economic context embedded in the process of collective action.

In this research, we aim to reveal the manifestations of neoliberalism in Academic Collective Action (ACA) as captured with prominent social/political psychological concepts of collective action and thus, to provide a preliminary groundwork for understanding the role of neoliberalism in organization, mobilization and empowerment dynamics during ACA. Therefore, we focus on dismissed academics' accounts about the manifestations of neoliberalism to understand it as an embedded contextual factor playing a role in the process of deprivation and collective action. This becomes crucial in understanding what can be accomplished and missed in applying prefigurative politics in tight spaces of oppression from the lenses of collective action (Cornish, Haaken, Moskovitz, \& Jackson, 2016).

\section{Research Context in Turkey: "Academia Does Not Bow!"}

Academic independence and freedom have long been under attack in Turkey through the neoliberalization of universities and state control of the agenda in science and education (Biner, 2019). However, since academics' peace declaration "We will not be a party to this crime" in January 2016, which called on the government to repeal the curfews in Kurdish towns ${ }^{2}$ and to restart the reconciliation process with Kurdish parties, the Justice and Development Party (Adalet ve Kalkınma Partisi, AKP) government and its apparatuses have reacted more harshly against academic freedom and independence by threatening academics, opening legal cases, jailing, and firing them from universities. This led peace academics to organize under the slogan of "Academia does not bow!" Later, following the July $15^{\text {th }}$, 2016 coup attempt, the government put in place a state of emergency, allowing it to release decree laws, firing thousands of civil servants from every branch of government at a time. These decree laws also mean that thousands of academics, including but not limited to peace academics, ${ }^{3}$ from $\mathrm{PhD}$ students to those well established in their careers, have been dismissed from their positions, barred from working in any university in the country, and oftentimes prevented from leaving the country by having their passports rescinded (Taştan \& Ördek, 2020).

Following the government's harsh reaction towards the academics and inspired by previous academic movements, academics formed and joined ACA to exercise their profession outside the university through Solidarity Academies ${ }^{4}$ (SAs) and other academic collectives formed in cities across Turkey. These collectives mainly aim to function as a means not only for these academics dismissed from their positions to maintain their scholarly dignity-even as they cannot maintain their livelihood-but also as a catalyst for prefigurative politics through the politicization and organization of a new group of scholars, creating activism around learning, teaching, and acquiring knowledge practices in a way that could not be done in the more restrictive environment of Turkey's formal institutions (Başer, Akgönül, \& Öztürk, 2017; Erdem \& Akın, 2019). In line with the patterns of resistance in tight spaces of oppression (Rosales \& Langhout, 2020), this wave of collective action currently continues via several small-scale vessels with two major aims: prioritizing societal peace through academic knowledge production and existing as academics outside the neoliberal university but not fully free from the larger neoliberal system (e.g., Tutkal, 2020).

\section{Neoliberalism: Relevance for Academia and Collective Action}

Despite some debates over its varied terminological uses and operationalizations (Venugopal, 2015), neoliberalism broadly refers to "new political, economic, and social arrangements within society that emphasize market relations, re-tasking the role of the state, and individual responsibility" (Springer, Birch, \& MacLeavy, 2016, p. 2). More specifically, neoliberalism (re)produces an economic and policy framework, consists of an ideology and imposes a form of governmentality based on reforms in social, cultural and educational realms, thereby extending into all areas of collective

1) https://www.hrw.org/news/2017/12/05/turkey-academics-trial-signing-petition

2) https://www.ohchr.org/documents/countries/tr/ohchr_south-east_turkeyreport_10march2017.pdf

3) https://barisicinakademisyenler.net/node/314

4) For the solidarity academies that are still active as of 31.08.2021, please see: https://biraradadernek.org/paydaslar/. For a documentary on the testimonies of solidarity academics, please see: https://www.youtube.com/watch?v=ToZ7_RE6ni8 
life (Giroux, 2015; Harvey, 2007). It discursively manifests itself through ideology, policy, state governmentality and individual governance (Springer, 2012). The elite actors hegemonically present neoliberal ideology as the only viable system. The social policies and political programs prioritize a free market system with private sector or corporate interests. The state engages in ultimate competition through institutional mediations, economic management systems and invasive social agendas. Individuals are governed based on knowledge production by auto-regulated selves who facilitate governance at a distance, thereby extending competitive markets to a cognitive and micro-level. Neoliberalism may also involve dynamics of oppression (Hardt \& Negri, 2017) and undemocratization (Brown, 2015).

In our work, based on participants' repertoire of resistance and in line with the recent critiques of neoliberalization of academia (Biner, 2019; Giroux, 2015; Harvey, 2007), we operationalize manifestations of neoliberalism in academia as explicit or latent attributions to the neoliberal system, which specifically correspond to the privatization of the public commons in economic, social, cultural, ethnic and academic spaces, harsh competition among academics, precarization of lower and middle classes, as well as the oppression of opposition voices by the use of physical, psychological or economic means and by criminalizing or terrorizing academics.

\section{Neoliberalization in Academia and Its Status in Turkey}

Life in higher education gets its share of neoliberalism through job insecurity, competition and precarization, student fees and tuitions, lack of health and pension rights as well as threats to academic independence and freedom, making academics vulnerable to state policies of totalitarian neoliberalism (Chatterjee \& Maira, 2014; Faucher, 2014). The main features of the neoliberal university are cultural and economic oppression of educators, the public university becoming a place for vocational training and teachers as customer-service workers, academic work as unpaid labor, and casualization of the labor force (Biner, 2019; Breu, 2014). In short, while the university itself was already not a space best suited to support a multitude of voices and the struggle for liberation and equality (Derrida, 2001; Spivak, 1999), the neoliberal university meant that the wheels of neoliberal oppression would target larger groups of academics and students (Giroux, 2015).

In Turkey, neoliberalization of higher education has been a continuing stepwise process since the 1980 military coup and the premiership of Turgut Özal between 1983-1987 (Aslan, 2014). The Council of Higher Education (CoHE) was established in 1981 to centralize all higher education institutions and other follow-up regulations redefined higher education as a "semi-public" service also allowing foundations to establish "nonprofit" private higher education institutions (Birler, 2012). The neoliberalization of higher education served a two-fold aim: meeting the private sector's need for a new market-oriented elite for the new neoliberal state order and suppressing political activism among university students and dissidence among academics after the military coup (Özen, 2002, as cited in Başç1, 2017). For instance, instead of improving public universities, the state served public subsidies and appropriated lands to foundation universities (Birler, 2012) while also centralizing and thereby hindering the autonomy of public universities (Kurul, 2010).

After the AKP came to power in 2002, the neoliberalization of higher education in particular (Birler, 2012) accelerated. Based on EU standards and in line with the global neoliberal turn, the early 2000s were characterized by educational reforms and regulations with an "entrepreneurship" approach, deepening the neoliberalization of education (Aslan, 2014). Accordingly, research, teaching and production are negatively affected by the privatization of higher education (Önder, 1996). As a reaction to these steps, academia in Turkey has also had a long history of collective action since 1985 to create a common space for independent academia, including the current academic collectives.

\section{Neoliberalism Embedded in the "Psychology" of Collective Action}

In the last two decades, neoliberalism has been one of the most prominent objects of contention and repertoire of resistance in recent waves of collective action around the world, as it manifests itself in various life domains (Cox \& Nilsen, 2007; Della Porta, 2015). This is also valid for academia: across the globe, the implications of the neoliberal university have remained the "hidden injuries" of academics (Gill, 2009). However, in recent periods, injuries have become more multifaceted and visible as the steady loss of economic and social rights in multiple domains and contexts. 
Against these deepening problems, academics have begun to raise their collective voice and organize in different parts of the world again with diverse strategies (Çetinkaya, 2017; Chatterton, Hodkinson, \& Pickerill, 2010; Mountz et al., 2015).

Beyond being a source of contention, neoliberalism is the embedded context in mutual constitution with our psychological and societal lives (Adams, Estrada-Villalta, Sullivan, \& Markus, 2019). Adams and colleagues (2019) suggest that neoliberalism constitutes some psychological processes, such as the "neoliberal selfways," consisting of alienation from societal concerns, excessively caring for the favorable representation of one's identities rather than its contents and enactments, pursuing self-focused novelties rather than collective experiences, and constantly down-regulating negative feelings against injustice. These neoliberal selfways can be traced back to the neoliberalized institutions, such as academia, which serve to reproduce the system both at micro- and meso-levels. As an embedded context rather than as an "external independent variable," neoliberalism stands around and within people's daily lives and its indications require elaborate scientific explorations in psychology, including the processes of collective action (McDonald, Gough, \& Wearing, 2019). As an economic, socio-political system and a dominant ideology, it can enclose our space, time and motivation for any collective practice of resistance, including academic knowledge production and scientific education (Davies \& Petersen, 2005; Federici, 2009).

As with the rest of a society's members, the subjects engaged or interested in collective action find themselves surrounded by or negotiating with this dominant sociopolitical and economic "system" (Teo, 2018). Similar to what de la Sablonnière and Taylor (2020) referred to as "collective inertia," in which group members confront a collective difficulty in the context of dysfunctional, social, and normative structures, we understand neoliberalism as constituting the context of dysfunctional, social, and normative structures, which makes it harder to fight from within (see also Badaan et al., 2018). For instance, the last wave of persistent academic strikes for pay and pension rights in United Kingdom has been recently interrupted by the Covid-19 pandemic (Palazzi, 2020). The situation gets even harder in national contexts which follow authoritarian politics given that resistance becomes more covert and collective action can be pursued in a narrower circle (Rosales \& Langhout, 2020). On the other hand, more and more deprived and oppressed communities use prefigurative politics to envision and try alternative and transformative systems to challenge the dominant flow (Trott, 2016). Although the levels of accomplishment remain to be seen, what we need to understand is how this new strategy, specifically targeted to change neoliberalized human relations, finds its way into the processes of collective action (Cornish et al., 2016).

Despite the well acknowledged role of structural inequalities and deprivations as a set of explanatory factors for the contention necessary to mobilize social change, and the importance of context for individual and collective behavior, neoliberalism has been mostly unnoticed in psychological collective action research, except a limited number of recent studies, which have treated neoliberalism mostly as an ideology (for a review see Bettache, Chiu, \& Beattie, 2020). Going beyond this limited literature, we consider neoliberalism as constituting a structural and contextual factor in which many sorts of individual and collective action takes place (Cornish, Campbell, \& Montenegro, 2018). We suggest that psychological collective action research may also develop new paths by considering how subjects speak about manifestations of neoliberalism in the steps leading to collective action.

Under these conditions, we are interested in the motivation to talk about manifestations of neoliberalism and how it can be explored within a collective action process. Understanding how people bring manifestations of neoliberalism in taking stances against escalating social inequalities/deprivations and engage in building an alternative for social justice will inform us more about the socio-political context in which collective action takes place and what might be at stake. Therefore, we dig into systematically deprived persons' accounts to understand their contentions in academia through their stories of mobilization in terms of explicit and latent manifestations of neoliberalism.

\section{Social and Political Psychological Guides for ACA}

Underlining the individual and the social constituents of behavior and locating the individual as the unit of analysis, research in social and political psychology provides a unique perspective on the study of collective action through explanatory models, and thus accounts for how and why individuals engage and stay in collective action (e.g., Thomas, McGarty, \& Mavor, 2009; van Zomeren, Postmes, \& Spears, 2008). Beside massive social dissidence and social protest, there are other forms of collective action aimed at social change (Della Porta \& Diani, 2009). Ingroup-oriented actions, 
individual level solidarity acts and psychological meaning of disadvantage as resistance (Leach \& Livingstone, 2015; Stroebe, Postmes, \& Roos, 2018) suggest a broader cluster and require further reflection on the forms, contents and processes of collective action. More specifically, recent forms of collective action are generally characterized by prefigurative politics that aim to build a new world in the shell of the old (Cornish et al., 2016) and resistance in tight spaces of oppression, which highlights the dynamics of structural violence (Rosales \& Langhout, 2020). Additionally, the subjectivity of persons engaged or interested in these other forms of collective action can further enlarge our theoretical horizon (Foucault, 1997; Teo, 2018). In short, a broader way of conceiving collective action from a social and psychological perspective requires considering small mobilizations and exploring how the movement is sustained and/or supported by its subjects through existing conceptual tools.

With such a vision, we examine ACA through social and political psychological perspectives (van Stekelenburg \& Klandermans, 2017; van Zomeren et al., 2008). We specifically focus on 1) injustice, inequalities and the resulting grievances, contentions as well as collective alignment through them (van Zomeren et al., 2008); 2) both material and social psychological resources such as collective efficacy beliefs, expectation of outcome, time, energy and collective self-objectification, and their mobilization (Drury \& Reicher, 2005; van Stekelenburg \& Klandermans, 2017; van Zomeren et al., 2008); social identity and politicization dynamics (Reicher, 1996, 2004; van Stekelenburg \& Klandermans, 2017); and empowerment as input and output of collective action (Drury \& Reicher, 2005, 2009). These processes might be influenced by neoliberalism as the latter is (at least ideologically) embedded in all social, economic and political relations (Bettache et al., 2020). Grievances persist and escalate on an individual basis without being transformed to collective processes, as the economic and political model relies on harsh competition and individualism and identities can become fashionable commodities rather than collective self-objectification as neoliberalism commodifies everything (Becker, Hartwich, \& Haslam, 2021; Teo, 2018). Resources are scarce as the socio-economic policies (away from equitable distribution) are centred on governing through accumulation by dispossession (Harvey, 2007). Finally, the processes of empowerment can become fragile as progressive social movements by oppressed minority groups can be easily repressed by neoliberal governments (Phillips, Adams, \& Salter, 2015). Following these conceptual categories, their potential links to neoliberalism, and based on our previous work (Acar \& Coşkan, 2020), we adopt a deductive template composed of grievances, resource mobilization, social identity and politicization of identities, and sustainment and empowerment of collective action to make sense of ACA in Turkey from the perspectives of participants.

\section{The Current Study}

The current study aims to reveal the manifestations of neoliberalism in the process of ACA as captured through psychological concepts of collective action. We do this by identifying the extent to which dismissed academics explicitly or latently refer to manifestations of neoliberalism when they talk about the processes preparing the ground for ACA (inequality, injustice, oppression), ACA itself (who is joining and who is staying on the borders and with which motivations) and the sustainment/enlargement of ACA. To this aim, we examine the perspectives of dismissed academics regarding the institutional structure of the university, their experiences of neoliberalism both inside and outside the university, their responses to recent waves of oppression, their existing and newly formed identities, their thoughts on the future of academia, and their professional roles outside the university. Through the conceptual categories of grievances, resource mobilization, social identities, identification and politicization, and sustainment and empowerment dynamics of collective action for dismissed academics' responses, we examine dismissed academics' explicit and latent remarks about manifestations of neoliberalism. This allows us to explore neoliberalism in relation to ACA from a general frame of prominent social/political psychological models of collective action.

\section{Method}

\section{Participants}

Participants were 21 dismissed academics from Turkey (10 women, ages ranged from 31 to 63), from PhD students to full professors. Of the 21 participants, 10 academics were actively engaged in academic collectives and 11 academics were 
interested in academic collectives but were disengaged from them at the time of the interviews. Initial participants were reached through personal contacts; a snowballing method was utilized to reach remaining participants. Participants were interviewed in Turkish, in person or via Skype between November 2017 and February 2018.

\section{Procedure}

Before starting the interviews, participants were informed about the purpose of the study, which was stated as understanding their experiences about academic collectives. Participants were asked to reflect on 1) their academic and political experiences and identifications, 2) the changes they have witnessed in universities and academia in general, 3) their experiences during and after their dismissals, and 4) how they dealt with or worked against the changes they experienced in the university as well as their dismissal (see Supplementary Materials). Of the 21 interviews, 20 were tape-recorded. One participant preferred not to have their interview tape recorded; in this case, the researcher took notes and later confirmed with the participant that notes were accurate. Interviews ranged in length from 33 to 118 minutes $(M=55$ minutes $)$.

\section{Analytic Procedure}

Participant accounts were analyzed based on principles of Qualitative Content Analysis (QCA) (Schreier, 2012), as well as an open coding approach (Strauss \& Corbin, 1998). QCA was utilized as it allows for the researcher to focus on specific aspects of data that are relevant to the research question. Specifically, QCA allowed us to produce our main categories related to social and political psychological concepts of collective action. We first followed a deductive analysis strategy to decide on the main categories, where we relied on existing theoretical explanations of collective action; namely we focused on 1) grievance, 2) resource mobilization, 3) social identity and 4) sustainment and empowerment of collective action. These four main categories shaped our coding frame. The grievance main category, for example, is coded based on descriptions of deprivation, social injustice and discrimination stemming from inequality.

Second, we explored manifestations of neoliberalism. Schreier (2012) notes that open coding can be adapted for use alongside QCA. Strauss and Corbin's (1998) process for open coding as described in Schreier (2012) was used to define manifestations of neoliberalism in our data. Based on engaged academics' accounts, we previously revealed that this ACA constitutes a strong example of contention and struggle against both incidental (i.e., criminalization of academic freedom) and structural (i.e., neoliberalization of academic practice) deprivations (Acar \& Coşkan, 2020). However, we did not specifically focus on the manifestations of neoliberalism in academia; instead, these were brought up by dismissed academics during data collection as part of their repertoires of resistance. This led us to further reflect on the relationship between contentions about neoliberalism and collective action and to code manifestations of neoliberalism in the data corpus. In particular, we sought descriptions of the four main collective action categories in light of our operationalization of neoliberalism corresponding to the privatization of the public commons in economic, social, cultural, ethnic and academic spaces, harsh competition among individuals, precarization of lower and middle classes, as well as the oppression of opposition voices by the use of physical, psychological or economic means and by criminalizing or terrorizing citizens (Biner, 2019; Giroux, 2015; Harvey, 2007). Thus, we did open coding for explicit and latent contents about the manifestations of neoliberalism in participants' responses to interview questions related to the four main categories and we refined those codes through our operationalization of neoliberalism. In this step, we did not limit ourselves to participants' explicit statements that included the word neoliberalism and we included their expressions with latent referrals that we were able to interpret as neoliberal manifestations.

Responses were independently coded by two authors and independently evaluated and verified by the third. Two authors further independently assessed statements from participants to decide if their answers could fall under the above-mentioned description of neoliberalism as it relates to their experiences in academia. The three authors then went over their assessments together and recoded any areas that did not overlap. 


\section{Results}

Below, we present the results for the manifestations of neoliberalism within their respective four main categories. When a participant's account is quoted, it contains an explicit or latent referral about the manifestations of neoliberalism (see Supplementary Material for those without indications of the influence of neoliberalism). We also provide participant frequencies and percentages to indicate the degrees to which content relevant to a particular category and its content of neoliberalism is mentioned by participants (see Table 1 ).

Table 1

QCA Content Summaries With Participant Frequencies and Percentages

\begin{tabular}{|c|c|}
\hline Main Categories (\% within sample) ${ }^{\mathrm{a}}$ & Manifestations of Neoliberalism (\% within category) \\
\hline $\begin{array}{l}\text { Structural and incidental disadvantages, inequalities and } \\
\text { deprivations expressed in relation to university and societal } \\
\text { change, academic collectives, and after the university } \\
n=19(\% 90.5)\end{array}$ & $\begin{array}{l}\text { - central control of academic and educational flow and content by CoHE } \\
\text { - corrupt publishing practices for high scores in the university } \\
\text { - limited financial resources to sustain academic collectives } \\
\text { - reproduction of hierarchical relationships and conflicts in the collectives } \\
\text { - academics' struggle to earn a living after being dismissed } \\
\text { - exploitation dynamics } \\
\text { - precarity, debt to state and private organizations } \\
\text { - loss of academia } \\
n=18(\% 94.75)\end{array}$ \\
\hline $\begin{array}{l}\text { Motivations and aspirations, efficacy beliefs, and material } \\
\text { and cognitive/intellectual resources } \\
n=17(\% 80.95)\end{array}$ & $\begin{array}{l}\text { - individual competition } \\
\text { - financial concerns related to state oppression } \\
\text { - (removal of) structural problems such as corruption in the university or the stifling of } \\
\text { academic work with bureaucratic workload } \\
n=8(\% 47.06)\end{array}$ \\
\hline $\begin{array}{l}\text { Academic identities, political identities, and } \\
\text { (dis)identification with academic collectives } \\
n=19(\% 90.5)\end{array}$ & $\begin{array}{l}\text { - institutionalized structural inequalities } \\
\text { - impossibility of critical thinking, academic freedom, collective knowledge production } \\
\text { and doing science for society in university } \\
n=8(\% 42.11)\end{array}$ \\
\hline $\begin{array}{l}\text { Gains and concerns toward continuing their academic } \\
\text { activities } \\
n=14(\% 66.67)\end{array}$ & $\begin{array}{l}\text { - a viable option against neoliberal academia in terms of its liberatory, independent and } \\
\text { relational dynamics } \\
\text { - limited inclusiveness of collectives, interpersonal issues or reproduced competitions, } \\
\text { and financial sustainment problems } \\
n=5(\% 35.71)\end{array}$ \\
\hline
\end{tabular}

Note. CoHE = Council of Higher Education.

${ }^{\mathrm{a}} N_{\text {Participants }}=21$.

\section{Main Category I: Grievances}

This main category included participants' accounts of manifestations of neoliberalism when they describe their grievances related to university and societal change, their grievances related to academic collectives, and their grievance/relative deprivation after dismissal from the university. Participants mentioned structural and incidental political, economic and social disadvantages, inequalities and deprivations based on their own or shared experiences. In total 19 participants described their grievances and among those, 18 of them referred to manifestations of neoliberalism (see Table 1).

Participants elaborated on grievances related to university and societal change that they or their colleagues experienced in terms of deprivations, inequalities and oppression in the university and higher education system as an institution before their dismissals. In their accounts, they frequently referred to neoliberal sources of these grievances, including but not limited to the central control of academic and educational flow (e.g., number of courses and students) and content (course material and articles) by CoHE, corrupt publishing practices, the precarization of academic professions, the pressure put on universities by the government, the CoHE and its nationalist depoliticization function, and 
the escalated loss of academic freedom. Expressing contempt and anger, they also emphasized their academic, political, social and economic needs and rights.

Some participants referred to the deprivations, inequalities and the dynamics of oppression more on a collective, even societal ground, putting the grievances into a historical context of the neoliberalization of higher education in Turkey and abroad. For instance, one participant $(\mathrm{P} 47)^{5}$ summarized the escalating privatization and the resulting inequality in the education system:

Every new government or ministry has come out with a draft about CoHE... it was a process during which I was thinking about how these drafts were biased and how education was commercialized, commoditized. After that, especially after 2004-2005, especially after the AKP government, commercialization and commoditization we have always mentioned, have become serious. Additionally, we were aware of preparations for personnel reform that came out as precarity.

Other participants focused more on their individual (or small work-group) experiences of deprivations and inequalities, such as difficulty in conducting scientific research due to heavy teaching loads.

Grievances related to academic collectives were discussed, specifically in terms of the difficulties experienced by the academic collectives due to state oppression, the neoliberal academic system, and the exclusionary dynamics (reproduction of inequalities, closed networks etc.) experienced by participants. Most accounts hint toward the difficulties of the sustainment of mobilization in academic collectives and the embedded neoliberal dynamics even within radical networks.

Despite a common emphasis on sustainability problems about grievances related to academic collectives, some participants focused on material/financial deprivations and structural grievances with more reference to the issues related to neoliberalism while others emphasized relational grievances. More specifically, the emphasis on neoliberalism included limited financial resources to sustain academic collectives' functioning as well as academics' struggle to earn a living after being dismissed and the reproduction of hierarchical relationships and conflicts in the collectives. For instance, one participant (P36) expressed his anger about financial limitations: "The biggest limitation of this alternative model of Solidarity Academies, the reason ... why I can't put my effort 24/7, is the financial barriers."

Participants further described their grievances after university life (i.e., post-dismissal) but unrelated to academic collectives. They expressed individual adversity related to the post-dismissal processes, mainly financial and state oppression as well as their concerns about what the university will become after them and how they will continue their professions. Some participants mentioned escalating financial concerns more at the individual level. However, there were many accounts referring to the neoliberal economy-politics, which included exploitation and consumption dynamics, precarity, debt to state and private organizations and loss of academia in non-organized participants, while it stayed limited to the loss of academia in only one organized participant. Furthermore, many of them described the academic isolation and self-distancing they are experiencing and expressed contempt:

Especially now [academia is] based on exploitation, totally dependent on consumption. If you don't [work], there's someone else [to work]. Well, there is already a system saying that you're a victim, you're compelled to it somehow. For that reason, I'm trying to keep myself out of that system as far as I can, but for how long? (P36)

Other participants referred less to personal financial concerns and expressed contempt based on professional concerns after the dismissals, expressing their thoughts about the future of academia and about reaching their students as well as producing knowledge for society. These thoughts also related to concerns about academic isolation as well as state repression in some cases.

5) P stands for participants and the numbers stand for the participants' age. 


\section{Main Category II: Resource Mobilization}

Participants referred to different resources at the individual as well as collective level when they discussed their situations and diverse actions after their dismissals. These resources included motivations and aspirations, efficacy beliefs, and material and cognitive/intellectual resources. Depending on their inclination toward individual mobility versus collective mobilization, the resources they mentioned also took individual (e.g., self-efficacy beliefs and familial financial support) or collective (e.g., previous collective experiences) qualifications. In total, 17 participants described their resources and among those, eight of them referred to manifestations of neoliberalism as an obstacle (see Table 1).

Participants expressed both existence and lack of motivations and aspirations toward collectivization of academia or individual academic work outside the university. Some participants emphasized the existence of motivations and aspirations. They frequently mentioned several sources of motivations and aspirations about academic collectives, in relation to solidarity with others and connecting or expanding academia outside the university in terms of developing alternative scientific production means. For example, one organized participant (P31) explained:

Disseminating all this knowledge, thinking and producing together... The universities are now too enclosed to produce something there. But this is a chance for us from another vantage point, especially for the instructors/professors to change some things of course. Not only from the university per se, given that many professors were dismissed from educational faculties, we can construct the experience of searching for the ways to change education itself or to pursue how this can be done.

These motivations sometimes came along with the acceptance of difficulty in creating a societal change combined with an aspiration of making a worldwide example. Manifestations of neoliberalism were mostly revealed when participants explained their motivation to change the neoliberal dynamics as exemplified by the narrowed down public space for societal dissent, the elimination of critical and alternative knowledge production, and the privatization of knowledge.

Other participants focused on motivations that were related to individual mobility or responsibilities (e.g., going back to their positions, focusing on their own studies or meeting child-care responsibilities). In some participants, there were also expressions toward lack of motivations and aspirations.

Participants' responses about continuing academic activities revealed discussions of self-and/or collective-efficacy (or lack thereof), with only rare reference to neoliberal dynamics specifically in terms of struggling for collective knowledge production and feeling efficacy-despair combination because of the employment and academic degree bans. For instance, one participant (P48) emphasized the importance of collective struggling for knowledge production: "In fact, knowledge production is a collective thing, it can't be done alone." Still, some of the organized participants emphasized that they did not feel a sense of collective efficacy.

Other participants highlighted their academic efficacy to keep up with academic activities on an individual level and still some others referred to lack of such feelings given financial and professional concerns. Indeed, dual feelings of both efficacy and despair largely prevailed because of the persisting employment and academic degree bans.

Participants also emphasized material and cognitive/intellectual resources by referring to (collective as well as individual) internal resources and external support by allies and family members, which helped dismissed academics to continue their academic survival through collective mobilization or individual mobility.

Cognitive or intellectual resources included common knowledge production and sharing, deliberation from academic hassles of the university, and previous academic experiences, which included manifestations of neoliberalism mainly in terms of the institutional hassles related with performance criteria, the suppression of critical thinking and collective production. For instance, one participant (P50) stated: "We have somehow fended off the publication fetishism, which is very nice. No one has to publish on topics they are not really focused on....No one presents their work if they are not satisfied with it."

Other participants also referred to intellectual resources as additional skills to survive economically while continuing their academic endeavors. Regarding material resources, some participants also emphasized external support from family and friends on finances and child-caring tasks, mostly following an emphasis on neoliberal dynamics in terms of financial limitations stemming from dismissals and employment bans. 


\section{Main Category III: Social Identities and Identifications}

Diverse social identities emerged from participants' responses to questions related to their social and political belongingness, their descriptions of being an academic as well as their connection to academic collectives. Therefore, this main category included academic identities, political identities, and (dis)identification with academic collectives. A total of 19 participants discussed their social identities and among those, eight of them revealed manifestations of neoliberalism (see Table 1).

Participants emphasized their academic identities and described how they defined what it means to be an academic by emphasizing the importance of producing knowledge for society, thinking critically, and being dissident. This emphasis was mostly accompanied by critical references to manifestations of neoliberalism in terms of the institutionalized structural inequalities, the impossibility of critical thinking, academic freedom, collective knowledge production and doing science for society in the neoliberalized university. Academic identities surfaced along with a politicized discourse; therefore, only accounts that specifically referred to academia and science were categorized here. In describing their academic identities, participants referred to their previous experiences in terms of academic and social struggles as well as getting organized as academics. For instance, several participants mentioned their active role in the Academy of Human Rights, ${ }^{6}$ Free University ${ }^{7}$ or Karaburun Science Congress (KSC). ${ }^{8}$ Furthermore, many participants emphasized the importance of a new collectivity for getting organized as academics. For instance, one participant (P38) stated:

... By organized I mean organized through communication, hence I see [academia] as an "institutionalization". Because I see it that way, I say that academic works should be outside of the academia. The academia, not as particular universities but as what universities together create with an institutional culture ...Hence, I think that academic work should get outside of this. If I say this in a more different and freer context, I would say that we don't need the universities as institutions and we don't need the academia as a psyche.

There was also some hesitation regarding academic identification. These were related to forcefully loosened ties with academia and the perception of academic profession as a job to make ends meet. Some participants expressed their academic efforts as an individual one.

Participants discussed their political identities in terms of previous and current experiences, rather than very specific ideologies or ties to specific political organizations. Similar to some accounts of academic identity, there was an emphasis on previous collective action experiences in generic terms, usually by referring to involvement with education unions, other NGO initiatives and student-years engagement in leftist organizations, without any reference to neoliberalism. Moreover, some participants also described how their current political identities are tied to academic collectives.

Other participants' accounts of political identity were more vague, though there were mentions of short-term engagement with a political group and previous collective action experiences, with rare references to issues related to neoliberalism:

My first dismissal was in 2006. 213 workers were fired from a left-governed university because they wanted to join a trade union. Back then I was the president of the university council. As a council, we have initiated a petition to get them back to work. We've collected 4000 signatures. (P60)

6) The Academy of Human Rights was established in 2010 by several academics and members from NGOs within the Human Rights Association to conduct work and studies on education about human rights (http://www.ihd.org.tr/category/c71-insan-haklari-akademisi/).

7) Free University is an organization established in 1994 by politically oriented academics and theoricians in Turkey (http://ozguruniversite.org/). Its aim is free and alternative education for the public.

8) Karaburun Science Congress is a political and academic endeavor of annual academic congress with the aim of bringing together academics with a progressive, leftist societal change agenda since 2006 (http://www.kongrekaraburun.org/). 
Participants also reflected upon their identification or disidentification with academic collectives based on their attitudes toward academia outside university and current activities and dynamics of academic collectives. Some participants expressed their identifications with academic collectives by reflecting upon the ACA process:

We also think about ourselves in terms of what we do. That was also one of the starting aims of Karaburun. Who are we? What are we doing? What are we thinking? What are we producing? Who is an academic, what is university and science? What did I accomplish? What am I experiencing? What am I struggling with? (P49)

Still, some other participants mostly expressed their disidentification or distance from academic collectives. Most of them explained why they have loose ties (or could not yet connect) with academic collectives based on their hesitation and/or concerns about the dynamics, functioning or academic contents of these collectives.

\section{Main Category IV: Perspectives on (Academic) Survival Outside the University}

Participants discussed their current and future academic and financial situation in terms of the gains and concerns toward continuing their academic activities outside the institutionalized university. In discussing those, they emphasized feelings of (dis)empowerment and visions to sustain ACA. A total of 14 participants described their perspectives and among these, five revealed manifestations of neoliberalism (see Table 1).

Participants discussed what they see as gains or benefits from the academic collectives and reflected on their current and future functionality. Some participants referred to the gains they perceive or acknowledge from the establishment and sustainment of academic collectives with descriptions of empowerment. They mostly referred to feelings of autonomy and liberation (i.e., being dismissed from the university but being part of the academic collectives) as well as their sense of relationality, collectivity, solidarity and diversity. When they were listing their current activities in the collectives, some also mentioned the expected functions of academic collectives such as new methods of academic production and emphasized the sustainment of ACA: "With the Solidarity Academy, we are pulling students out of institutionalized education and creating an alternative public space" ( $\mathrm{P} 48)$.

As exemplified in this account, most of them discussed gains as a hope against the existing neoliberalized university and they referred to manifestations of neoliberalism in terms of privatized knowledge production and surveilled and censored academic freedom by emphasizing how academic collectives prefigures a path away from precarization and market-based institutionalization in explaining gains.

Some participants explained their concerns based on losses (e.g., a regular salary and a stable workspace) that cannot be compensated yet in the academic collectives, their uncertainties regarding the limited inclusiveness of collectives, interpersonal issues or reproduced competitions, and financial sustainment problems. Some of these concerns focused on issues such as financial sustainment, academic production, equal relationships and sufficient inclusivity in academic collectives. There were also some concerns about having lost academic space or quality in the university for good, such as:

And this should not be considered only in terms of student-based factors. Of course, the education quality drops as the student quality decreases. What I mean by student quality, [students who] don't like reading, researching, who are against critical thinking, don't ask questions, don't know how to ask questions but do know how to fill complaints against instructors. Hence, when we return, the academia won't be as we are thinking and dreaming of. Maybe it has never been such a place, but we were never falling so far from it. (P31)

Other accounts were more pessimistic regarding academic collectives but did not include references to neoliberalism.

\section{Discussion}

Collective action for social change involves several forms (Della Porta \& Diani, 2009). Some forms consist of small groups of people (rather than crowds) aiming to build new worlds in the shell of the old one (i.e., prefigurative politics). 
They generally act in a socio-cultural space (rather than in the street) and require longer periods of sustainment to create change or to resist especially in tight spaces of oppression. We focus on one such mobilization for progressive societal change in times of strengthened neoliberal politics and escalating authoritarian oppression: academic collectives in Turkey. We consider these academic collectives within the general theoretical lines of collective action with academics as either collectively or individually mobilized subjects (Acar \& Coşkan, 2020). The current research, however, focuses on dismissed academics' accounts of the manifestations of neoliberalism to understand it as an embedded contextual factor playing a role in the process of deprivation and collective action.

A general overview of the findings suggests that, following the theoretical lenses of collective action in psychology, participants' discussions of ACA contain a wide range of references to neoliberalism. Depending on the ACA involvement of participants, expressions of grievances took a collectivized versus individualized tonality about the deprivations and inequalities related with the university and academic collectives. There were also some expressions of resentment and anger against corruption and oppression as well as acceptance of corruption and oppression (e.g., "only few raised voices against injustices in university," P50) besides feelings of disturbance against the existing system.

Manifestations of neoliberalism were most frequent in the grievances category, suggesting that neoliberalism is perceived as a factor majorly shaping economic, political and social deprivations and inequalities. Participants emphasized the felt effects of neoliberalism through a socio-historical basis: the structural policy changes in the university and oppression against academics escalating in the 1980's and reaching a climax with the final dismissals of 2016, followed by academic mobilization and ongoing problems. More strikingly, the manifestations of neoliberalism under grievance accounts related not only to university and societal change but also to academic collectives and life after the university. This further suggests that neoliberal dynamics can infiltrate collective action and sustainment processes as well as survival after dismissals by accompanying socio-political deprivations and inequalities.

When participants discussed their resources and how they mobilized them, they emphasized their motivations and aspirations, efficacy beliefs, or material (financial or commodities) and non-material (intellectual and cognitive) resources for collective mobilization and/or individual mobility. This highlights that, rather than being limited to materiality, resources can be very diverse, encompassing motivational, intellectual and affective domains in ACA (Drury \& Reicher, 2009; McCarthy \& Zald, 1977). The manifestations of neoliberalism surfaced here as well, though less frequently. Some participants were especially motivated toward collectively changing the neoliberal dynamics of academia and felt efficacious using their cognitive and intellectual resources through academic collectives, while other participants expressed that they use their resources relatively more for individual mobility. This means that manifestations of neoliberalism, as an embedded contextual factor, can add an explanatory power of resource mobilization, especially when collective resistance is feasible.

In line with the existing collective action literature, our results indicated politicized identities: academic identity was more often discussed with a politicized tonality by some participants, and often referred back to previous experiences of organizing as academics, with some emphases on contentions against and repertoires of resistance about past academic deprivations and manifestations of neoliberalism. Political identities were generally described more vaguely, which might be specific to the ACA in question. Past experiences also indicated a social identity ground for embeddedness and further mobilization (Thomas, Zubielevitch, Sibley, \& Osborne, 2020). Hence, past action and established identities in relation to the contentions against neoliberalism could be thought of as an active ingredient of both resource mobilization and future collective action organization; they accelerate social mobilization but also the organization of resources for those mobilizations (Klandermans, van der Toorn, \& van Stekelenburg, 2008). Furthermore, in line with recent understandings of identification in terms of being "activist" and "non-activist" (van Zomeren, 2015), identification (or the lack thereof) with academic collectives was often discussed by participants less involved in ACA through feelings of exclusion and interest in individual mobility which might be promoted by neoliberal ideology, thereby leading people to question the shared identity of the collective.

Participants' perspectives on academic survival outside the university highlighted what they lost when they were made to leave academia, and the benefits of working outside the university, projecting onto the (dis)empowering sides and the sustainment of ACA. Manifestations of neoliberalism in this category surfaced only in some participants and mostly, if not always, in their accounts of gains, rather than concerns, reflecting these participants' ongoing motivation 
to counter neoliberalism in relation to the institutional academic system and indicating the content of prefigurative politics in ACA.

In short, academic collectives are formed and mobilized mostly by academics who have experienced the consequences of academic neoliberalization over the years and who were finally deprived of institutionalized academia. Most of them have previous political and academic experience of acting for societal change, mobilize several non-material resources, have strong political as well as academic identifications, are politicized with the recent waves of dismissals, and still struggle to reach resources to sustain ACA. Furthermore, both individual and collective factors are in charge of participating and sustaining ACA, thereby constituting dismissed academics as producing and reproducing subjects of prefigurative politics.

The manifestations of neoliberalism reveal that the felt effects of this economic and socio-political system are present in many factors that can explain ACA, but especially so in grievances, resource mobilization and politicized identities. In other words, neoliberalism can be embedded in the antecedents as well as in the process of collective action to different degrees and can affect current and future decision-making and actions of the subjects. This can be understood in terms of triggering context as well as an awareness toward the cause of ACA but it also hints to the probability of infiltration of an existing system and ideology into the organization, mobilization and sustainment of collective action. More specifically, beyond being a source of contention, neoliberalism can be targeted in constructing a repertoire of resistance: Dismissed academics combine grievances, resources and motivations into a politicized identity (i.e., academic) in the embedded political economic context, namely neoliberalism, which lead them to collective self-objectification as well as to sustain collective action itself (Drury \& Reicher, 2005, 2009). This also suggests a rarely addressed attitude of collective actors: they make specific use of affirmative discourse for social change by indicating the institutional system's failure, rather than the pure negative expression of contention (e.g., Braidotti, 2015). However, neoliberalism can also permeate through the processes of collective action, creating vulnerabilities for mobilization of resources, identification with and sustainment of ACA, especially on the individual level. Still, our findings also suggest that the collective self-objectification based on the repertoire of resistance can serve as a buffer against disempowerment especially under escalating oppression and continued deprivation (Drury \& Reicher, 2009).

Finally, the data collection process also revealed an important quality relating to this ACA: as we were contacting dismissed academics for participation in our research, some of them expressed active engagement in academic collectives, while others stated a relatively distant interest and audience-level engagement. They are diverse in terms of identification with academic collectives, strategies of mobilization and mobility and concerns about personal sustenance and ideas about the functioning of collectives. However, they all have a salient interest in discussing academic collectives. We suggest that future research delving into the loose engagement will be promising in understanding how prefigurative politics in tight spaces of oppression can be strengthened with the contribution of loosely engaged individuals.

This research also bears some limitations. First, our exploration of ACA was based on using the most explicit constructs of the prominent collective action theories without very detailed operationalization of each construct. This means that we did not apply strict differentiation between processes. For instance, some grievances were intertwined with resource mobilization and politicized identities. Therefore, this research only constitutes a first attempt in understanding ACA within and beyond the existing theoretical frames. Further explorations will be needed to understand the dynamics of ACA in terms of existing and new models. Second, although we provide an insight into manifestations of neoliberalism as a contextual factor as reflected in participants' accounts, an in-depth understanding of the dynamics through which neoliberalism is entangled before and during the collective action mobilization process would require further investigation by asking participants explicitly about its role and influence.

\section{Conclusion}

Most collective action theories are driven by data of street mobilization with relatively shorter periods that do not specifically focus on the socio-political and economic context beyond its role in grievances. However, collective action that uses prefigurative politics under the conditions of political oppression, such as ACA in Turkey, is less often addressed and should be assessed more systematically. The current research suggests that such collective action, as 
followed through the existing conceptual tools of collective action, can inform us about the role that neoliberalism plays in its dynamic. As a first exploratory attempt, our research provides preliminary evidence that neoliberalism, captured through its manifestations reported by dismissed academics, can serve as an embedded contextual factor to account for the process of collective action. During ACA, the manifestations of neoliberalism can be a source of grievance, an obstacle to resource mobilization, a motive for dissident identification, and a barrier against emancipation to differing degrees. They become mostly visible in terms of grievances, but also in understanding how it can infiltrate mobilization and organization (in collective identifications, politicization, motivations and finding or allocating resources). Considering the global trends of oppression against autonomous knowledge production, and the need to support academic resistance, we hope these findings stimulate further research about the dynamics of ACA and solutions to sustain academic freedom and independence.

Funding: The authors have no funding to report.

Acknowledgments: We would like to emphasize that this research could not have been realized without the participants who heartfully shared their time and space, their stories, their ideas and their imaginations with us. We would also like to thank the acting editor, Johanna Vollhardt and the anonymous reviewers for their constructive suggestions for this manuscript.

Competing Interests: The authors have declared that no competing interests exist.

Author Note: We acknowledge that a portion of the data has been previously analyzed and is published (Acar \& Coşkan, 2020).

\section{Supplementary Materials}

The Supplementary Materials contain a list of the questions asked during the interviews and participants' quotes that were categorized under each theme but did not involve manifestations of neoliberalism (for access see Index of Supplementary Materials below).

\section{Index of Supplementary Materials}

Coşkan, C., Acar, Y. G., \& Bayad, A. (2021). Supplementary materials to "Revealing the manifestations of neoliberalism in academia: Academic collective action in Turkey" [Interview questions and additional quotes]. PsychOpen GOLD.

https://doi.org/10.23668/psycharchives.4957

\section{References}

Acar, Y. G., \& Coşkan, C. (2020). Academic activism and its impact on individual-level mobilization, sources of learning, and the future of academia in Turkey. Fournal of Community \& Applied Social Psychology, 30(4), 388-404. https://doi.org/10.1002/casp.2455

Adams, G., Estrada-Villalta, S., Sullivan, D., \& Markus, H. R. (2019). The psychology of neoliberalism and the neoliberalism of psychology. Journal of Social Issues, 75(1), 189-216. https://doi.org/10.1111/josi.12305

Aslan, G. (2014). Neo-liberal transformation in Turkish higher education system: A new story of a turning point: Draft proposition on the higher education law. Fournal for Critical Education Policy Studies, 12(2), 255-283.

Badaan, V., Jost, J. T., Osborne, D., Sibley, C. G., Ungaretti, J., Etchezahar, E., \& Hennes, E. P. (2018). Social protest and its discontents: A system justification perspective. Contention, 6(1), 1-22. https://doi.org/10.3167/cont.2018.060102

Başç1, P. (2017). Social trauma and telecinematic memory: Imagining the Turkish nation since the 1980 coup. London, England: Palgrave Macmillan.

Başer, B., Akgönül, S., \& Öztürk, A. E. (2017). “Academics for Peace” in Turkey: A case of criminalising dissent and critical thought via counterterrorism policy. Critical Studies on Terrorism, 10, 274-296. https://doi.org/10.1080/17539153.2017.1326559

Becker, J. C., Hartwich, L., \& Haslam, S. A. (2021). Neoliberalism can reduce well-being by promoting a sense of social disconnection, competition, and loneliness. British fournal of Social Psychology, 60(3), 947-965. https://doi.org/10.1111/bjso.12438 
Bettache, K., Chiu, C. Y., \& Beattie, P. (2020). The merciless mind in a dog-eat-dog society: Neoliberalism and the indifference to social inequality. Current Opinion in Behavioral Sciences, 34, 217-222. https://doi.org/10.1016/j.cobeha.2020.06.002

Biner, Z. Ō. (2019). Precarious solidarities: "Poisonous knowledge" and the academics for peace in times of authoritarianism. Social Anthropology, 27(S2), 15-32. https://doi.org/10.1111/1469-8676.12701

Birler, Ö. (2012). Neoliberalization and foundation universities in Turkey. In K. Inal \& G. Akkaymak (Eds.), Neoliberal transformation of education in Turkey (pp. 139-150). New York, NY, USA: Palgrave Macmillan.

Braidotti, R. (2015). Posthuman affirmative politics. In S. E. Wilmer \& A. Zukauskaite (Eds.), Resisting biopolitics: Philosophical, political, and performative strategies (pp. 30-56). New York, NY, USA: Routledge.

Breu, C. (2014). The post-political turn: Theory in the neoliberal academy. In J. Di Leo \& U. Mehan (Eds.), Capital at the brink: Overcoming the destructive legacies of neoliberalism (pp. 241-258). Ann Arbor, MI, USA: Open Humanities Press, Michigan Publishing, University of Michigan Library.

Brown, W. (2015). Undoing the demos: Neoliberalism's stealth revolution. New York, NY, USA: Zone Books.

Çetinkaya, E. (2017). Turkish academics' encounters with the index in social sciences. In H. Ergül \& S. Coşar (Eds.), Universities in the neoliberal era (pp. 61-92). London, England: Palgrave Macmillan.

Chatterjee, P., \& Maira, S. (2014). The imperial university: Race, war, and the nation-state. In P. Chatterjee \& S. Maira (Eds.), The imperial university: Academic repression and scholarly dissent (pp. 1-50). Minneapolis, MN, USA: University of Minnesota Press.

Chatterton, P., Hodkinson, S., \& Pickerill, J. (2010). Beyond scholar activism: Making strategic Interventions inside and outside the neoliberal university. Acme: An International E-journal for Critical Geographies, 9, 245-275.

Cornish, F., Campbell, C., \& Montenegro, C. (2018). Activism in changing times: Reinvigorating community psychology Introduction to the special thematic section. fournal of Social and Political Psychology, 6(2), 526-542. https://doi.org/10.5964/jspp.v6i2.1111

Cornish, F., Haaken, J., Moskovitz, L., \& Jackson, S. (2016). Rethinking prefigurative politics: Introduction to the special thematic section. Fournal of Social and Political Psychology, 4(1), 114-127. https://doi.org/10.5964/jspp.v4i1.640

Cox, L., \& Nilsen, A. G. (2007). Social movements research and the "movement of movements": Studying resistance to neoliberal globalisation. Sociology Compass, 1(2), 424-442. https://doi.org/10.1111/j.1751-9020.2007.00051.x

Davies, B., \& Petersen, E. B. (2005). Neo-liberal discourse in the academy: The forestalling of (collective) resistance. Learning \& Teaching in the Social Sciences, 2(2), 77-98. https://doi.org/10.1386/ltss.2.2.77/1

De la Sablonnière, R., \& Taylor, D. M. (2020). A social change framework for addressing collective action: Introducing collective inertia. Current Opinion in Psychology, 35, 65-70. https://doi.org/10.1016/j.copsyc.2020.03.006

Della Porta, D. (2015). Social movements in times of austerity: Bringing capitalism back into protest analysis. Cambridge, United Kingdom: Polity Press.

Della Porta, D., \& Diani, M. (2009). Social movements: An introduction. Oxford, United Kingdom: Blackwell.

Derrida, J. (2001). The future of the profession or the university without condition (thanks to the "Humanities," what could take place tomorrow). In T. Cohen (Ed.), facques Derrida and the humanities: A critical reader (pp. 24-57). Cambridge: Cambridge University Press.

Drury, J., \& Reicher, S. (2005). Explaining enduring empowerment: A comparative study of collective action and psychological outcomes. European fournal of Social Psychology, 35, 35-58. https://doi.org/10.1002/ejsp.231

Drury, J., \& Reicher, S. (2009). Collective psychological empowerment as a model of social change: Researching crowds and power. Journal of Social Issues, 65, 707-725. https://doi.org/10.1111/j.1540-4560.2009.01622.x

Erdem, E., \& Akın, K. (2019). Emergent repertoires of resistance and commoning in higher education: The solidarity academies movement in Turkey. South Atlantic Quarterly, 118(1), 145-163. https://doi.org/10.1215/00382876-7281660

Faucher, K. X. (2014). Alienation and precarious contract academic staff in the age of neoliberalism. Confero: Essays on Education, Philosophy and Politics, 2, 35-71. https://doi.org/10.3384/confero.2001-4562.141007a

Federici, S. (2009). Education and the enclosure of knowledge in the global university. ACME: An International E-journal for Critical Geographies, 8(3), 454-461.

Foucault, M. (1997). Ethics: Subjectivity and truth (The essential works of Michel Foucault 1954-1984: Volume One; P. Rabinow, Ed.; R. Hurley, Trans.). New York, NY, USA: The New Press.

Gill, R. (2009). Breaking the silence: The hidden injuries of neo-liberal academia. In R. Flood \& R. Gill (Eds.), Secrecy and silence in the research process: Feminist reflections (pp. 228-244). New York, NY, USA: Routledge. 
Giroux, H. (2015). Democracy in crisis, the specter of authoritarianism, and the future of higher education. Fournal of Critical Scholarship on Higher Education and Student Affairs, 1, 101-113.

Hardt, M., \& Negri, A. (2017). Assembly. Oxford, United Kingdom: Oxford University Press.

Harvey, D. (2007). A brief history of neoliberalism. Oxford, United Kingdom: Oxford University Press.

Klandermans, B., van der Toorn, J., \& van Stekelenburg, J. (2008). Embeddedness and identity: How immigrants turn grievances into action. American Sociological Review, 73(6), 992-1012. https://doi.org/10.1177/000312240807300606

Kurul, N. (2010). Türkiye üniversitelerinde 1980 sonrası dönem: Insanın özgürleşmesi amacından akademik kapitalizme geçişin öyküsü [Turkey universities in the period post-1980: The story of the transition from the purpose of human emancipation to academic capitalism]. Bilim ve Gelecek, 71, 1-18.

Leach, C. W., \& Livingstone, A. G. (2015). Contesting the meaning of intergroup disadvantage: Towards a psychology of resistance. Journal of Social Issues, 71(3), 614-632. https://doi.org/10.1111/josi.12131

McCarthy, J. D., \& Zald, M. N. (1977). Resource mobilization and social movements: A partial theory. American fournal of Sociology, 82(6), 1212-1241. https://doi.org/10.1086/226464

McDonald, M., Gough, B., \& Wearing, S. (2019). Social psychology, consumer culture and neoliberalism: A response to Phelps and White (2018). Fournal for the Theory of Social Behaviour, 49(3), 394-400. https://doi.org/10.1111/jtsb.12214

Mountz, A., Bonds, A., Mansfield, B., Loyd, J., Hyndman, J., Walton-Roberts, M., . . Curran, W. (2015). For slow scholarship: A feminist politics of resistance through collective action in the neoliberal university. ACME: An International fournal for Critical Geographies, 14(4), 1235-1259.

Önder, İ. (1996). Üniversite eğitim emperyalizminin saldırısı altında [The University is under attack by educational imperialism]. Bilim ve Ütopya, 24, 8-9.

Palazzi, F. (2020, April 30). Your classes are on Zoom and your teaching staff is being cut. facobin. Retrieved from https://jacobinmag.com/2020/04/academia-uk-essex-university-layoffs-higher-education

Phillips, N. L., Adams, G., \& Salter, P. S. (2015). Beyond adaptation: Decolonizing approaches to coping with oppression. fournal of Social and Political Psychology, 3(1), 365-387. https://doi.org/10.5964/jspp.v3i1.310

Reicher, S. (1996). Social identity and social change: Rethinking the context of social psychology. In W. P. Robinson (Ed.), Social groups and identities: Developing the legacy of Henri Tajfel (pp. 317-336). London, England: Butterworth.

Reicher, S. (2004). The context of social identity: Domination, resistance, and change. Political Psychology, 25(6), 921-945. https://doi.org/10.1111/j.1467-9221.2004.00403.x

Rosales, C., \& Langhout, R. D. (2020). Just because we don't see it, doesn't mean it's not there: Everyday resistance in psychology. Social and Personality Psychology Compass, 14(1), 1-12. https://doi.org/10.1111/spc3.12508

Schreier, M. (2012). Qualitative content analysis in practice. London, England: Sage.

Spivak, G. C. (1999). A critique of postcolonial reason: Toward a history of the vanishing present (pp. 423-431). Cambridge, MA, USA: Harvard University Press.

Springer, S. (2012). Neoliberalism as discourse: Between Foucauldian political economy and Marxian poststructuralism. Critical Discourse Studies, 9(2), 133-147. https://doi.org/10.1080/17405904.2012.656375

Springer, S., Birch, K., \& MacLeavy, J. (2016). An introduction to neoliberalism. In S. Springer, K. Birch, \& J. MacLeavy (Eds.), The handbook of neoliberalism (pp. 1-14). London, England: Routledge.

Strauss, A., \& Corbin, J. (1998). Basics of qualitative research techniques. Thousand Oaks, CA, USA: Sage.

Stroebe, K., Postmes, T., \& Roos, C. A. (2018). Where did inaction go? Towards a broader and more refined perspective on collective actions. British fournal of Social Psychology, 58, 649-667. https://doi.org/10.1111/bjso.12295

Taştan, İ. Ö., \& Ördek, A. (2020). A report on academic freedoms in Turkey in the period of the state of emergency. Retrieved from http://insanhaklariokulu.org/wp-content/uploads/2020/04/A-Report-on-Academic-Freedoms-in-Turkey.pdf

Teo, T. (2018). Homo neoliberalus: From personality to forms of subjectivity. Theory \& Psychology, 28(5), 581-599. https://doi.org/10.1177/0959354318794899

Thomas, E. F., McGarty, C., \& Mavor, K. I. (2009). Aligning identities, emotions, and beliefs to create commitment to sustainable social and political action. Personality and Social Psychology Review, 13(3), 194-218. https://doi.org/10.1177/1088868309341563

Thomas, E. F., Zubielevitch, E., Sibley, C. G., \& Osborne, D. (2020). Testing the social identity model of collective action longitudinally and across structurally disadvantaged and advantaged groups. Personality and Social Psychology Bulletin, 46(6), 823-838.

https://doi.org/10.1177/0146167219879111 
Trott, C. D. (2016). Constructing alternatives: Envisioning a critical psychology of prefigurative politics. fournal of Social and Political Psychology, 4(1), 266-285. https://doi.org/10.5964/jspp.v4i1.520

Tutkal, S. (2020). Power, knowledge, and universities: Turkey's dismissed "academics for peace." Critical Studies in Education. Advance online publication. https://doi.org/10.1080/17508487.2020.1783335

Van Stekelenburg, J., \& Klandermans, B. (2017). Individuals in movements: A social psychology of contention. In C. Roggeband \& B. Klandermans (Eds.), Handbook of social movements across disciplines (pp. 103-139). Cham, Switzerland: Springer.

van Zomeren, M. (2015). Collective action as relational interaction: A new relational hypothesis on how non-activists become activists. New Ideas in Psychology, 39, 1-11. https://doi.org/10.1016/j.newideapsych.2015.04.001

van Zomeren, M., Postmes, T., \& Spears, R. (2008). Toward an integrative social identity model of collective action: A quantitative research synthesis of three socio-psychological perspectives. Psychological Bulletin, 134, 504-535.

https://doi.org/10.1037/0033-2909.134.4.504

Venugopal, R. (2015). Neoliberalism as concept. Economy and Society, 44(2), 165-187. https://doi.org/10.1080/03085147.2015.1013356 